\title{
前浜地形変化の支配要因とバームの形成過程 DOMINANT FACTORS DETERMINING FORESHORE CHANGES AND PROCESSES OF BERM FORMATION
}

\author{
宇多高明*.小俣 篤**. 竹㴊 勉*** \\ By Takaaki UDA, Atsushi OMATA and Tsutomu TAKEBUCHI
}

\begin{abstract}
In order to investigate the mechanism of topographic changes of the foreshore due to wave action, field data obtained at Ajigaura Beach once a week since 1975 were analyzed. Dominant factors determining foreshore changes are found to be energy flux of the deep water waves, grain size on the foreshore and foreshore slope. Accretion or erosion of the foreshore can be classified using these three parameters. Beach lamination process of the foreshore was investigated through the field observations at Ajigaura Beach. It is found that berm can be formed by some sublayers composed of coarse and fine materials or only by one layer composed of fine material. These changes can be elucidated by the wave climate change.

Keywords: foreshore, topographic change, dominant factors, berm formation, beach lamination
\end{abstract}

\section{1. まえがき}

前浜地形の変化を波や底質の条件と結び付けた研究は 数多い. Rector ${ }^{1)}$, Nayak $^{2)}$ は次元解析をもとに二次元 実験結果を整理し，平衡状態における前浜勾配やバーム の高さを波と底質の条件を用いて定式化した。また， Sunamura ${ }^{3)}$, 武田ら ${ }^{4)}$ は現地海岸のデータを用いて同様 の定式化を行った。

一方, 前浜地形変化は, 汀線の前進・後退や, 沿岸砂 州の発生・消失とも関係付けられる. 岩垣ら ${ }^{5)}$ は, Johnson $^{6)}$ による暴風海浜と正常海浜の分類に底質粒径 と波高の比を縮尺効果として取り入れ，沿岸砂州の発生 限界を示した. 分類に用いたパラメーターは, 次元解析 より得られたものであり，砕波帯内での漂砂現象を直接 観察して得られたものではない。堀川ら”は, Kemp ${ }^{8)}$ による phase difference の考え方に従い，海底勾配を含 んだパラメーターを導入して平衡海浜形状の分類を行っ た.この分類には砕波帯内での波浪变形の効果が取り込 まれているので, 岩垣らの分類より現象を物理的によら

\footnotetext{
* 正会員 工博 建設省土木研究所海岸研究室長 （３05 茨城県つくば市大字旭 1 )

** 正会員 建設省土木研究所海岸研究室 (同上)

*** 前・建設省土木研究所海岸研究室
}

えている. 以上のように, 次元解析をもとに海浜変化を 論ずる場合, 各パラメーターと物理現象との関係が明瞭 でなく，現地海岸にこれらを適用する場合に，一致・不 一致の原因を明確にしにくい，この点からすると，砕波 帯内での海浜変形は浮遊した底質の挙動に強く支配され るという考え方に立ち, 海浜変形の分類を行った服部 $ら^{9)}$ の方法は, 砕波帯内での底質移動の機構にまで踏み 込んで海浜変形をとらえる意味において，現象を物理的 に扱っていると考えられる.

著者らは，阿字ケ浦海岸のデータより汀線の前進・後 退之前浜の堆積・侵食とが必ずしも対応しないこと ${ }^{10)}$, 底質の粒径は時空間的に変化する ${ }^{11)}$ ので代表值を単純 に決定できないことを明らかにしている，また，砕波帯 内においては浮遊形態での底質移動が活発であり ${ }^{10), 12)}$, したがって砕波帯内での海浜過程の解明を進めるうえ で，底質の浮遊機構や浮遊底質の輸送機構を明らかにす ることが重要と考えている，さらに，時間的に変化する 波浪の条件と海浜地形との動的な応答関係を知ることも 重要な課題である. 加藤ら ${ }^{13)}$ は波崎海岸における海浜 断面測量の結果を用いて, 来襲波のエネルギーフラック スをパラメーターとして岸沖漂砂による汀線変化のモデ ル化を行った。このモデルでは，エネルギーフラックス を用いる物理的な根拠に堀川らの分類法を引用してい 


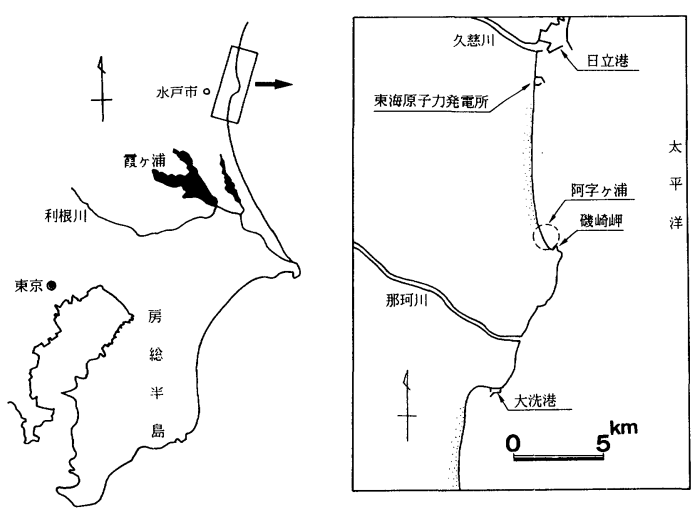

図-1 阿字ケ浦海岸位置図

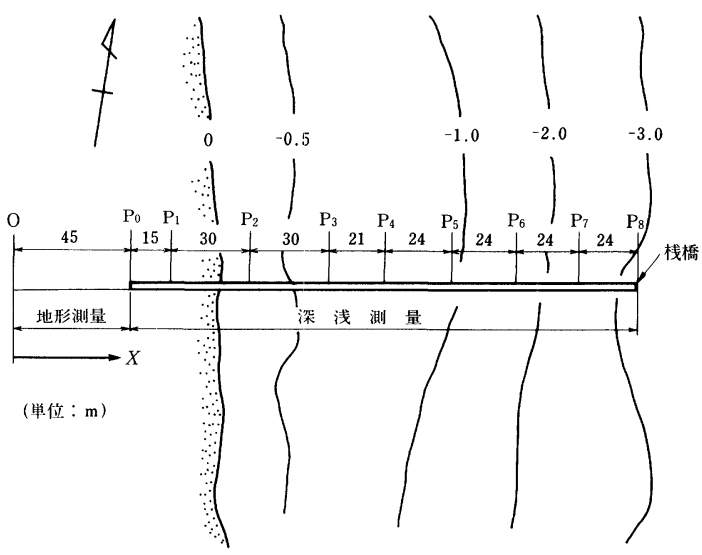

図-2 漂砂観測用栈橋

る.

前浜地形変化を考えるうえでの重要な要素の 1 つは, 底質粒径の変化である. 前浜の底質粒径が時空間的に変 化することは良く知られており，たとえば Clifton ${ }^{14)}$ は 前浜の断面内に層状構造が存在することを示している.

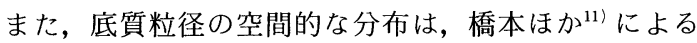
阿字ケ浦海岸での掘削調査によっても調べられた。この ような底質粒径の空間的変化は, 波浪条件の変化に伴う 海浜地形変化の結果として生じると考えられる.した がって, 岸沖漂砂による地形変化の機構を解明するうえ において，底質の時空間的な変化過程を明らかにするこ とは重要な課題となる。しかし，現地海岸における前浜 地形，底質および波浪条件の相互関連を論じた研究は少 ないのが現状である。

本研究では, 前浜の堆積, 侵食機構を明らかにするこ とを目的として，阿字ケ浦海岸 (図一1参照) で取得し た定期観測データを解析した。定期観測は，同海岸にあ る漂砂観測用栈橋（図一-2）を用いて，1975 年より現在 まで毎週 1 回の割合で継続的に行われている ${ }^{15}$. この定 期観測データをもとに，波による前浜地形変化の支配要
因を検討した ${ }^{16)}$. また，特にバーム形成時における底質 粒径の時空間的な変化を，定期観測以外に別途実施した 現地観測により調べた ${ }^{17}$. これにより，バームを構成す る底質の粒径変化を明らかにする．また，定期観測デー 夕を加えて解析し, バーム形成時の底質粒径変化と波浪 条件の関係について論ずる.

\section{2. 前浜地形変化の支配要因}

\section{（1）支配要因の抽出}

二次元海浜変形と波浪, 底質条件との関係を扱った研 究は数多い. 岩垣ら ${ }^{5)}$ は波形勾配と波高粒径比をパラ メーターとして暴風海浜と正常海浜の分類図を作成し た. その後も多くの研究が行われており，たとえば砂 村 ${ }^{18)}$ は汀線位置の変化モデルを提案している.これら の研究においては, 二次元的な地形変化の代表パラメー ターとして汀線位置が用いられている。しかし，現地海 岸では汀線が後退しつつバームが発達する場合も多 く ${ }^{17)}$, 汀線位置の後退が前浜の侵食と必ずしも対応しな い.このため, 二次元海浜変形を考えるうえで, 汀線位 置の変化が前浜の堆積, 侵食の判定基準になり得るかは 疑問である. 加藤ら ${ }^{13)}$ は波崎海岸での現地観測データ をもとに短期的な地形変化をモデル化する際に, 海浜断 面上の T.P. 約 $0.7 \mathrm{~m}$ の位置の水平方向変位量を用いて いる. その理由は，この地点の地形変化が岸沖漂砂によ る地形変化の特性を良く表わすためと考えられる. 岸沖 漂砂によって生ずる典型的な地形変化であるバームの形 成・消失は，平均潮位以上の場所で生じる，そのため， 汀線位置の変化より, 前浜地形の変化の方が岸沖漂砂に よる地形変化を良く表わすと考えられる. 結局, 汀線付 近における二次元的意味での Net の岸沖漂砂の方向は, それによって決定される前浜部の地形変化より判断すべ きと考える.このため本研究では, 前浜地形の堆積・侵 食の判定を次のようにして行った，最初に，毎週の地形 測量結果を用い, 連続した 2 回の測量結果を重站合わせ た.このとき, T.P. $0 \mathrm{~m}$ より陸上の前浜地形が堆積傾 向の変化を示せば，その 1 週間内における汀線付近の Net の岸沖漂砂の方向は岸向之判断した．侵食の場合は この逆である (図一3参照).

前浜の測量は 1 週間ごとであることから，変化の最小 時間スケールは 1 週間になる. バームの形成は $1 \sim 4$ 週 間の期間を要するものがほとんどであり ${ }^{10)}$ ，その期間に 大きく波浪条件が変わることは少ない，一方，バームの 消失時には，一般に数日で大きな地形変化が生じるが, 堆積に要する時間スケールからみて, バーム消失後の数 日間に著しい堆積変化が生じることはない.したがって, 前浜地形の侵食・堆積傾向を 1 週間の時間スケールで判 断することに問題はないと考えられる. また，潮位変化 


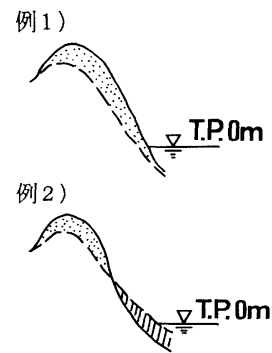

〈堆積の例〉

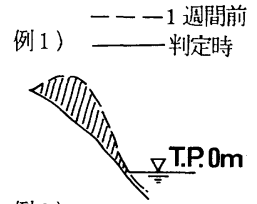

例 2)

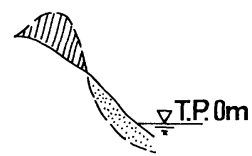

〈侵食の例〉

\section{図-3 堆積・侵食の判定例}

に伴う地形変化は，1 潮汐間でほぼ打ち消されることが わかっている10).

砕波帯内においては，波のトラフレベル付近でも高濃 度の浮遊砂が観測されており ${ }^{12), 20)}$, この浮遊漂砂が Net の岸沖漂砂量に影響すると考えられる. しかし, 既往の 小型実験ではこのような浮遊現象が再現されていないと 判断され，このことが縮尺効果による実験と現地との地 形変化の差異をもたらす大きな原因と考えられる.たと えば，阿字ケ浦海岸での定期観測結果と岩垣らの分類

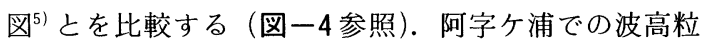
径比 $\left(\overline{H_{0}^{\prime}} / d_{50}, こ こ に \overline{H_{0}^{\prime}}\right.$ は 1 週間の平均有義波高) は 図示するように $5 \times 10^{2} \sim 10^{4}$ の範囲にあり, 岩垣らの分 類図によればほ亡んどのデータが暴風海浜の範囲にある ことになる.しかし，実際には正常海浜の海浜断面形状 もみられることから，この分類図は, 現地海岸での地形 変化に適用できないことになる.

武田ら ${ }^{4)}$ は, 阿字ケ浦海岸の北に位置する那珂海岸で の観測デー夕を用い, $H_{b} / g T^{2}$ と $d / H_{b}\left(H_{b}\right.$ : 砕波波高, $g$ : 重力加速度, $T$ : 周期, $d$ : 底質の平均粒径) によ りバームの形成領域を分類した. また，ここに用いられ たパラメーターは, 砕波帯内における漂砂の移動方向の 判定にも用いられている ${ }^{19)}$. 武田らのパラメーターを用 いて, 本研究で定義した前浜の侵食・堆積のデー夕を分
類したところ，明瞭な分類結果を得ることはできなかっ た.これは, 武田らの分類がバームの形成領域を求めて いるのに対し, 本研究のデー夕は前浜での漂砂の移動方 向を示していること, 武田らのパラメーターには前浜勾 配等, 局所的な前浜地形の影響が直接的に取り込まれて いないことに起因すると考えられる，そこで，本研究で は, 前浜の堆積・侵食を支配する因子として, 物理的な 解釈が行いやすいことを条件とし, できるだけ単純なパ ラメーターを採用することにした。

現地海岸における底質の浮遊，およびその輸送・底質 の掃流等は, 砕波帯内の流体運動や波による流速を支配 する来襲波のエネルギーフラックスに強く依存すると考 えられる. そこで, 外力の代表パラメーターとしてエネ ルギーフラックスを用いる. 従来より, 二次元地形変化 をもたらす外力の代表パラメーターとしてしばしば沖波 波形勾配が使われてきた。 今回用いた波浪データより求 めた週平均の換算沖波有義波高 $\overline{H_{0}^{\prime}}$ とその波形勾配 $\overline{H_{0}^{\prime} / L_{0}}$ の関係を図一5に示す。沖波有義波高の変化が波 形勾配亡良く対応し, 波形勾配の変化は波高の変化とほ ぼ同義になることがわかる，また，波高の変化はエネル ギーフラックスの変化とよく対応する．図一 5 にもみら れるように, $\overline{H_{0}^{\prime}}$ の変化に比べ $\overline{H_{0}^{\prime} / L_{0}}$ の変化は小さく, 分類の精度の面からしても，エネルギーフラックスを採 用する方がよい. また, 砂の移動形態, および底質の浮 遊限界を判断するうえで，底質の粒径は重要な影響をも つ.これらのことから, 前浜の堆積・侵食の分類をエネ ルギーフラックス $F$ と粒径で整理した。ただし，地形 測量は 1 週間ごとに行っているので， 1 週間の積分され た地形変化より，侵食・堆積を判定することになる．そ こで, 沖波観測データより日平均波高, 周期を求め, 毎 日の $F$ を計算し, さらにそれを 1 週間積分して平均値 $\bar{F}$ を求め，これを代表值とした。 なお，毎日の波向資 料がないため，以下の解析では波向は考慮していない. また，底質デー夕は $\bar{F}$ を計算する初日の夕イミングで

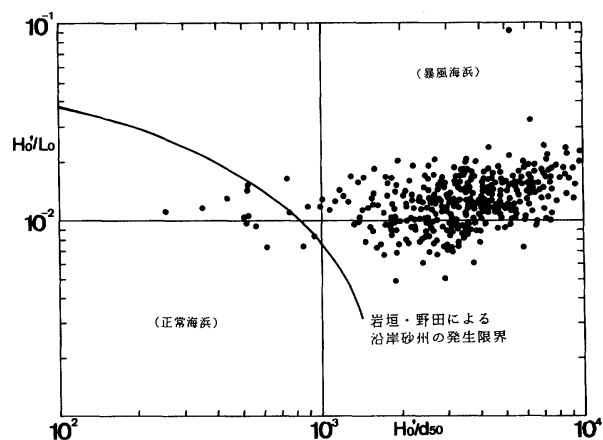

図-4 岩垣らによる正常海浜と暴風海浜の分類と現地データの 比較

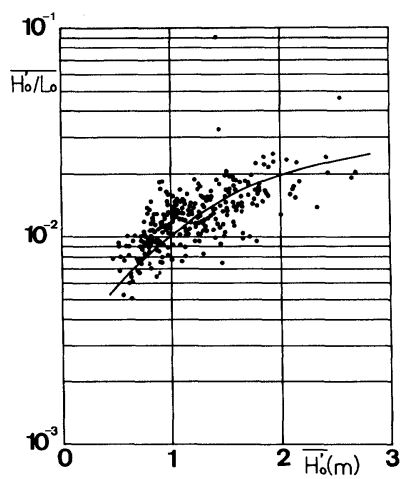

図一5 $\overline{H_{0}^{\prime}}$ と $\overline{H_{0}^{\prime} / L_{0}}$ の相関 
の $\mathrm{P}_{0}$ 地点（図一2参照）における底質の中央粒径 $d_{50}$ を用いた。

前浜に底質が堆積することによってバームが形成さ れ, 前浜が急勾配になると堆積は生じなくなり, それ以 上の地形変化は生じなくなる. 同様に, 侵食により前浜 勾配がある程度緩くなると, それ以上の侵食は生じなく なる。このように，堆積・侵食には単に外力や底質の特 性だけでなく，地形形状自体も影響する。ここでは前浜 の侵食・堆積を判定する 1 パラメーターとして, 地形を 代表する特性値として前浜勾配 $i_{f}$ を選んだ。ここで, $i_{f}$ は T.P. $0 \mathrm{~m}$ 以上の前浜（バームがある場合にはバー ム頂より沖) の平均的な勾配とした。

（2） $\bar{F} ， \boldsymbol{d}_{50} ， \boldsymbol{i}_{f}$ による前浜の堆積・侵食の分類

1975 年 6 月から 1986 年 12 月までの 11 年 6 か月間の 地形測量データを用いて, 前浜の堆積・侵食の分類を 行った．横軸に $\bar{F}$, 縦軸に $d_{50}$ をとり, $i_{f}$ を 3 つの範 囲に分けて整理した（図一6，7，8）. 図一6 が $i_{f} \leqq 0.04$, 図一7 が $0.04<i_{f} \leqq 0.06$ ，図一8 が $i_{f}>0.06$ の範囲にあ るデータを示す。なお, データ取得期間の平均前浜勾配 は 0.052 である.このとき用いた $i_{f}$ の值は $d_{50}$ 之同様, $\bar{F}$ を計算する際の初日における值である，各図をみる とデータにばらつきはあるものの, $\bar{F}$ が大きいと侵食, 小さいと堆積となる傾向が明らかである. さらに $\bar{F}$ が ある程度大きくても， $d_{50}$ が大きいと堆積または安定傾 向亡なる. そこで, この傾向を調べるために, 堆積・侵 食を示すデータの分類境界を全体的なデータの分布より 判定して図中の実線と破線で示した。境界が明瞭でない ため, 侵食を示すデー夕のみより判断した境界を実線, 堆積を示すデータのみより判断した境界を破線とした. 同じ粒径において破線で示す境界より $\bar{F}$ が大きくなる とほとんどのデー夕は侵食を示す，また，実線で示す境 界より $\bar{F}$ が小さい場合には, ほとんゼが堆積または安 定となる，各図の実線より右側の侵食領域においても， $d_{50}$ が $0.5 \mathrm{~mm}$ 以上では必ずしも侵食となっていない。 図中に示した実線および破線は次式で表わされる.

$$
d_{50}=C \bar{F}^{0.8} \text {. }
$$

ここに $d_{50}$ は $\mathrm{mm}, F$ は $\mathrm{t} \cdot \mathrm{m} /(\mathrm{m} \cdot \mathrm{s})$ の単位をもつ.また, $C$ は定数である (表一1参照). 表より $i_{f}$ が大きくなる とCの值は大きくなることがわかる.つまり， $i_{s}$ が大 きいほど侵食されやすいという結果を得る．各図より， $\bar{F}>2 \mathrm{t} \cdot \mathrm{m} /(\mathrm{m} \cdot \mathrm{s})$ ではほとんどが侵食傾向を示し, $\bar{F}<$ $4 \mathrm{t} \cdot \mathrm{m} /(\mathrm{m} \cdot \mathrm{s})$ および $d_{50}>0.5 \mathrm{~mm}$ ではほとんどが堆積 傾向を示す．また，前浜勾配が大きいと侵食されやすい 傾向を示す．データのばらつきの原因としては，一部の データに関して 1 週間という時間スケールが適切ではな いこと, 沿岸漂砂による地形変化が考慮されていないこ と, $F$ が沖波から求められているため浅海の海底地形

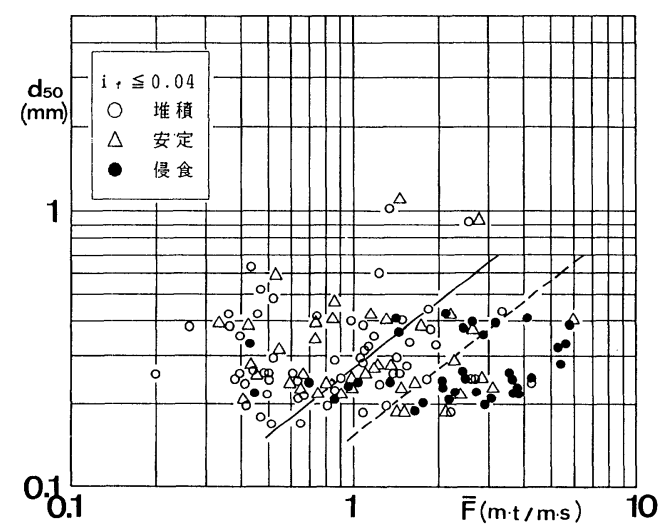

図一6 前浜の堆積・侵食の分類図 $\left(i_{f} \leqq 0.04\right)$.

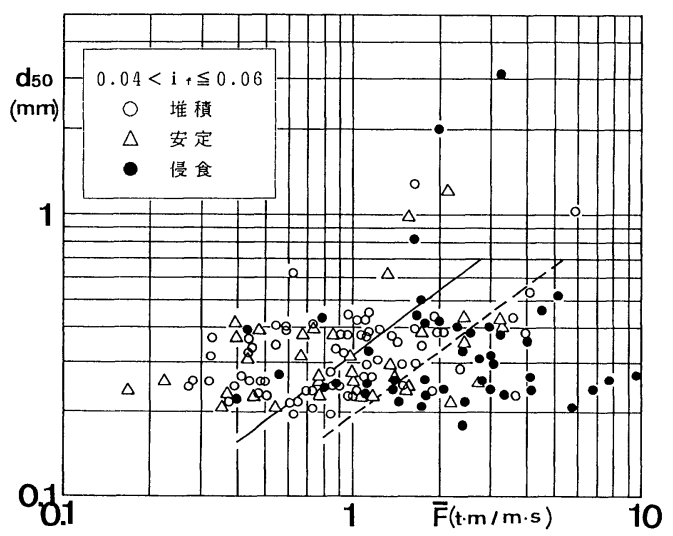

図-7 前浜の堆積 ・侵食の分類図 $\left(0.04<i_{f} \leqq 0.06\right)$

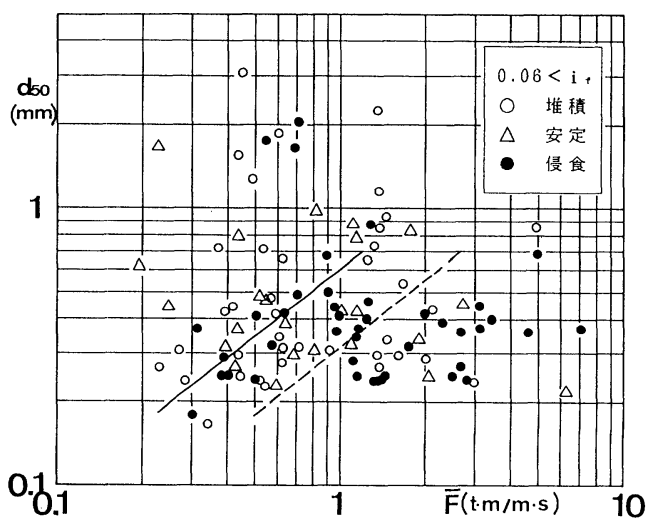

図-8 前浜の堆積・侵食の分類図 $\left(i_{f}>0.06\right)$

変化の影響が考慮されていないことなどを挙げることが できる。それにもかかわらず，ここで用いた $\bar{F}, d_{50}$, $i_{f}$ により前浜の侵食, 堆積の傾向はよく分類されてい ると考えられる. 以上のことから，前浜の地形変化は入 射波のエネルギーフラックス，前浜の底質中央粒径，前 


\begin{tabular}{|c|c|c|}
\hline$i \neq$ の範囲 & 境界線 & $\mathrm{C}$ \\
\hline \multirow{2}{*}{$i_{f} \leqq 0.04$} & 実線 & 0.27 \\
\hline & 破線 & 0.15 \\
\hline \multirow{2}{*}{$0.04<i_{t} \leqq 0.06$} & 実線 & 0.31 \\
\hline & 破線 & 0.19 \\
\hline \multirow{2}{*}{$0.06<i_{f}$} & 実線 & 0.60 \\
\hline & 破線 & 0.31 \\
\hline
\end{tabular}

浜勾配に強く影響されると考えられ，これらに波向，海 底地形等を加えたパラメーターにより支配されると考え られる。

\section{3. バームの形成過程に関する現地観測}

\section{（1）観測 方 法}

現地観測は，阿字ケ浦海岸に設置されている漂砂観測 用栈橋を利用し，栈橋中心軸の陸側延長上に測線を設け て行った。バームの掘削調査は，1987 年 5 月 21 日と 1988 年 2 月 9 日 2 月 22 日に実施した。 1987 年 5 月 21 日には，バーム内部の底質構成を明らかにするために， バーム頂点位置から沖側に約 $10 \mathrm{~m}$ の範囲を掘削し，掘 削溝側面を写真撮影した。1 1988 年 2 月 9 日〜2月 22 日 の調査では，バームの形成過程を明らかにするために， 前浜部の $48 \mathrm{~m}$ の範囲において水準測量, 底質採取およ び写真撮影を毎日行った。この範囲は，定期観測のデー 夕によればバームが形成されやすい範囲にあたる，底質 は測量範囲内の 10 点で約 $500 \mathrm{~g}$ ずつ採取した。また, 観測最終日の 2 月 22 日には測線上に溝（延長約 $20 \mathrm{~m}$, 幅約 $3 \mathrm{~m}$, 深さ約 $1 \mathrm{~m}$ ) を掘り, 底質の堆積状況を調べ た.

\section{（2）観測結果とその考察}

a) 1987 年 5 月 21 日の観測結果

2 月 19 日から 5 月 21 日までの間におけるバームの発 達に伴う海浜断面形の変化を図一9に示す。なお本報で は，栈橋中心軸上の $\mathrm{P}_{0}$ 地点より陸側 $45 \mathrm{~m}$ の位置に基 準点 $\mathrm{O}$ を設け，それより沖方向に $X$ 軸をとった（図一 2 参照)。また，T.P. $0 \mathrm{~m}$ を基準として鉛直上方に $Z$ 軸 を定めた。

図一9より，バームの形成状況を調べると，2月 19 日 から 3 月 5 日の間に $35 \mathrm{~m} \leqq X \leqq 55 \mathrm{~m}$ の範囲でバームの 発達がみられたが，その後はそれより陸側の 20 $\mathrm{m} \leqq X \leqq 40 \mathrm{~m}$ の範囲で土砂が堆積し，5月 21 日には前 浜勾配 $i_{f}=0.068$, バーム頂点高 $Z_{B} \doteqdot 1.6 \mathrm{~m}$ のバームか 形成された.このバームは 4 月 9 日までにはほぼ安定し， その後 5 月 21 日まで前浜の断面形はほとんど変化しな かった。バーム形成時（2月 19 日〜4月 9 日）前後の期

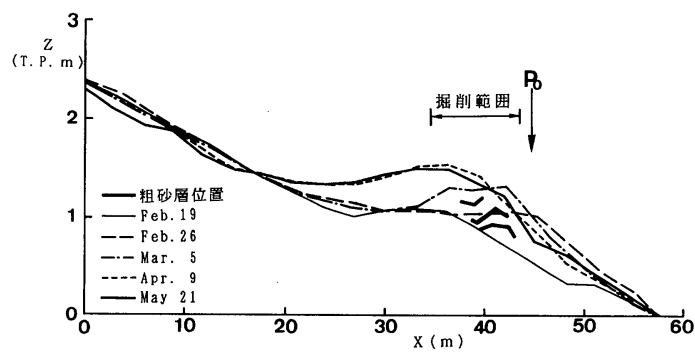

図-9 前浜断面変化（1987 年 2 月 19 日～5 月 21 日）

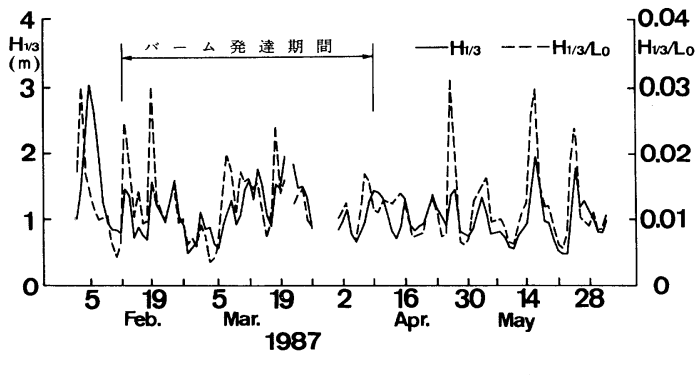

図-10 バーム形成時前後の期間の波浪条件

(1987 年 2 月 5 月)

間の波浪条件を図一 10 に示す．日平均有義波高 $H_{1 / 3}$ は バームの発達期間を通じて $0.5 \sim 2.0 \mathrm{~m}$ の間で変動して いた。特に， $Z_{B}$ が大きく増加した 3 月 5 日〜 4 月 9 日 の間では $H_{1 / 3} \doteqdot 1.5 \mathrm{~m}$ の波が数日おきに来襲したことが 特筆される.

図ー9の $35 \mathrm{~m} \leqq X \leqq 43 \mathrm{~m}$ の範囲における掘削断面の 一部を写真一 1 に示す. バームは粗砂層と細砂層から成 り，各層は $2 \sim 10 \mathrm{~cm}$ の厚さを有している．細砂層の砂 は当海岸によくみられる $d_{50} \fallingdotseq 0.3 \mathrm{~mm}$ の砂である。一 方, 粗砂層には, 一部粒径数 $\mathrm{mm} \sim 1 \mathrm{~cm}$ 程度の砅も混 じっており, 平均的に $1 \mathrm{~mm}$ 程度の粗砂から成っている. このようなバーム内での層状の堆積は Clifton ${ }^{14)}$ の調査 報告と一致している. 次に，粗砂層に注目して，その岸 沖方向分布を調べた. 5 月 21 日の海浜断面形状と, 当 日撮影した一連の写真より求めた粗砂層の位置を図一9 に示した． 粗砂層の位置は当日の測量結果をもとに写真 より読み取ったため，その精度は土 $10 \mathrm{~cm}$ 程度と考えら れる. 粗砂層は 2 月 26 日と 3 月 5 日に測定されたバー 么頂付近の前浜形状とほぼ平行に分布していることか ら, 各層は 2 月 19 日から 3 月 5 日の間に形成され, バー ムは粗砂, 細砂が繰り返し堆積することにより発達し， その結果バーム内部に層状模様が形成されたと推定され る。そこで，2月 19 日から 3 月 5 日までの前浜部の状 況を写真一2，3，4 に示した。 2 月 19 日にはほぼ前浜全 域が細砂で覆われていた（写真-2）。しかし，2月 26 日には海浜の広い範囲が礫で覆われているのが明らかで 


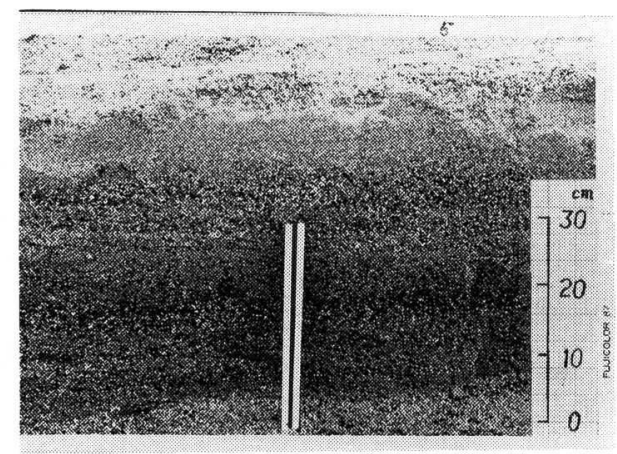

写真-1 バーム内の層状構造

あり (写真一 -3$), 3$ 月 5 日には再び砂により覆われた (写 真一4). 2 月 26 日における磞に覆われた海浜表面の状 況は, 図一9に示した粗砂層中心軸のうち上から 2 番目 の粗砂層の形成時の状況を示すと考えられる．また， 2 月 19 日～26日の波浪条件（図一10）をみると，2月 23 日には $H_{1 / 3} \fallingdotseq 1.7 \mathrm{~m}$ の波浪が来襲している. 2 月 26 日 ～ 3 月 5 日の間でも $H_{1 / 3} \fallingdotseq 1.2 \mathrm{~m}$ の波浪が来襲している ことから，粗砂はある程度波高が高いときに打ち上げら れたと考えられる。なお，3月 5 日〜4月 9 日までの堆 積時に形成された断面については, 掘削位置が最終的な バーム頂より沖に限定されているので，その構造は明ら かでない.

b） 1988 年 2 月 9 日 2 月 22 日の調査結果

観測期間中の代表時期における海浜断面の全体形を図 -11に示す.ここに, 沖合部のくさび状の地形は橋脚 の洗掘を表わす. 2 月 11 日と 18 日の断面形はともにス テップ状の地形を有し， $X \doteqdot 130 \mathrm{~m}$ で海底勾配が急変し て深くなっていた，さらに，図一11に示した測量範囲 における毎日の地形変化を, 2 月 9 日を基準とした地盤 高変化量 $\Delta Z$ として図一12 に示す. 地盤高は 2 月 15 日 まで $X \geqq 50 \mathrm{~m}$ で変化していたが, その後堆積範囲が陸 側へと広がり, 19 日以後その変化は $X \geqq 35 \mathrm{~m}$ で生じた. また，地形変化は連続的でなく断続的に生じており，12 〜13 日，18１9 日，19２0日，20２1 日に大きかった ことがわかる.このように, 1 連のバーム形成過程の中 でバームが形成される範囲やその形成速度は一定ではな い. 観測期間中の波浪条件（図一13）によると，日平均 有義波高 $H_{1 / 3}$ はほとんど $1 \mathrm{~m}$ 以下であり, 静榣であっ た。また, 波形勾配 $H_{1 / 3} / L_{0}$ は 2 月 10 日に 0.025 と比 較的大きな值を示すものの, それ以後は 0.007 より 0.015 の範囲に分布している. また, 図中には比較的著 しい地形変化のみられた期間の初日を矢印で示した。地 形変化の大きいときは, 波浪条件が変化したときと対応 し, バームの形成過程が波浪条件の変化とよく対応する ことを示す.

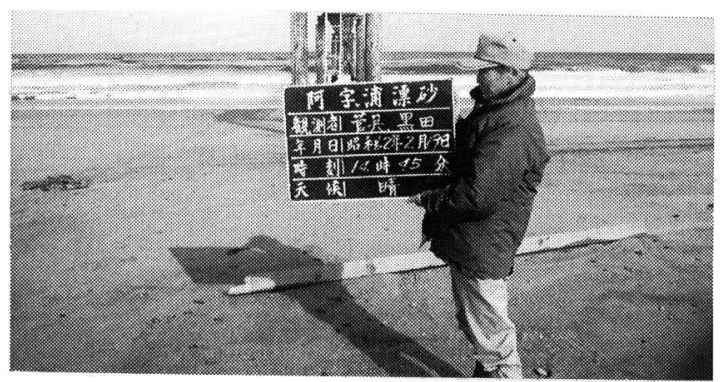

写真－2 前浜の状況（1987 年 2 月 19 日）

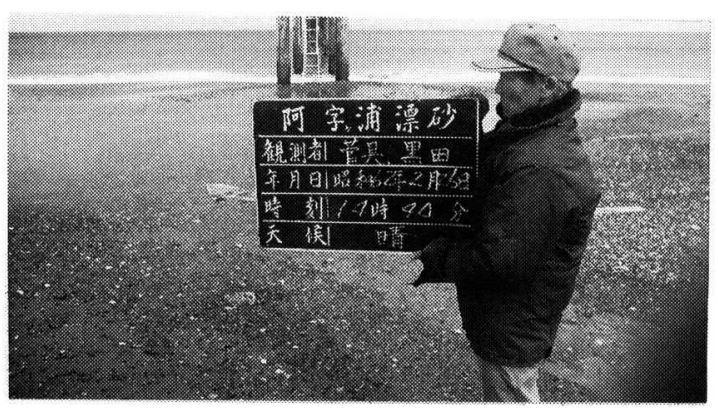

写真-3 前浜の状況（1987 年 2 月 26 日）

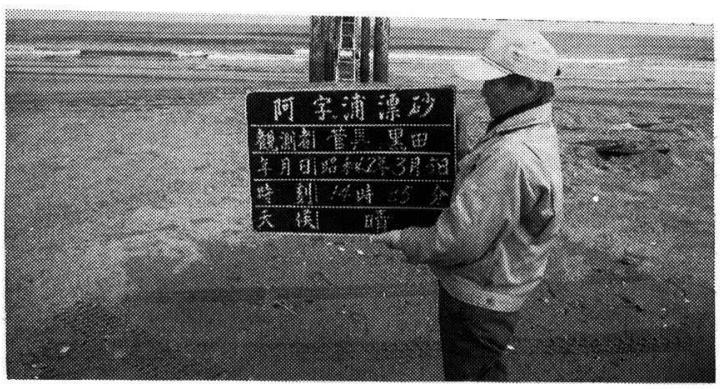

写真 -4 前浜の状況（1987 年 3 月 5 日）

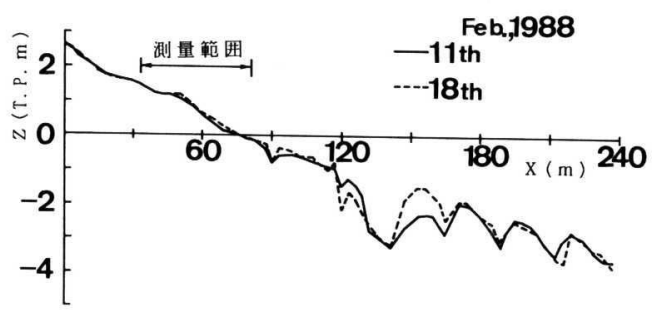

図-11 栈橋に沿う海浜断面形 (1988 年 2 月 11 日と 2 月 18 日)

次に, 代表地点の地盤高 $Z$ と底質の中央粒径 $d_{50}$ の 経時変化を図一14に示す. 代表地点としてバームの最 終的な頂点位置付近の $X=51 \mathrm{~m}$, 汀線付近の $X=81 \mathrm{~m}$, およびそれらの間の $X=60 \mathrm{~m}$ 地点を選んだ. $X=51 \mathrm{~m}$ 地点の地盤高 $Z$ は 2 月 15 日以前にはほとんど変化せ ず, その後堆積の傾向を示した. $X=60 \mathrm{~m}$ 地点の地盤 


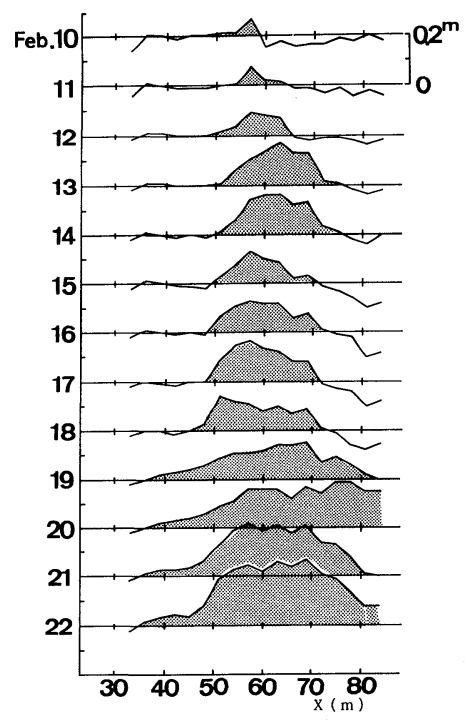

図-12 前浜地盤高変化量 $\Delta Z$ の岸沖分布

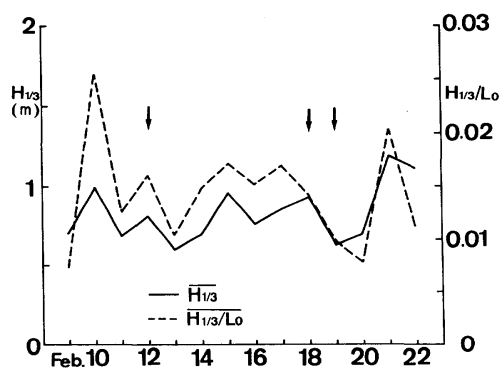

図-13 バーム形成時の波浪条件 (1988 年 2 月)

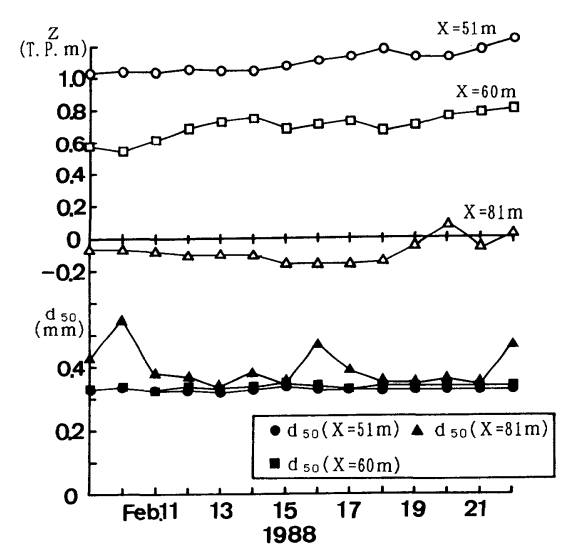

図-14 代表地点の地盤高 $Z$ と底質粒径 $d_{50}$ の経時変化

高も，2月 10 日〜 14 日の間に大きく上昇したが，その 後はあまり変化していない. 以上のように地形変化は生 じているものの, $d_{50}$ は両地点とも終始約 $0.3 \mathrm{~mm}$ であっ て変化は小さい. 汀線よりやや沖側の $X=81 \mathrm{~m}$ 地点で
は 2 月 18 日以前に $Z$ は平均的に減少傾向にあり，その 一方で $d_{50}$ は 2 月 10 日，16 日に $0.4 \mathrm{~mm}$ を越える粗粒 が現われた. さらに $Z$ が増加した 18 日以降にも粗粒と なった。 以上の観測結果より, 汀線付近では粒径変化が あったものの, 前浜では粒径が変化しなかったことがわ かる. 2 月 22 日に小型バックホーにより， $30 \mathrm{~m} \leqq X \leqq$ $50 \mathrm{~m}$ の範囲で深さ $1 \mathrm{~m}$ の掘削を行ったが, 層状の模様 は形成されていなかった。このことは, 前回の観測結果 と大いに異なる。

以上より, バームが発達する際に生じる前浜底質の時 空間的な変化過程は一定したものでなく，粗砂と細砂が 交互に堆積する場合と, 細砂のみが堆積する場合とがあ ることがわかった. そして，それらの相違点としては次 の点が挙げられる.

(1) バームの形成が始まってから安定するまでのバー 厶頂点高さ $Z_{B}$ の変化量は, 粗砂と細砂が交互に堆積す る場合約 $1 \mathrm{~m}$ であったのに対して, 細砂のみ堆積する 場合は $0.2 \mathrm{~m}$ と小さかった.

(2) バーム形成時の $H_{1 / 3}$ は，平均的にみて両者とも に $1 \mathrm{~m}$ 程度であったが, 前者では $H_{1 / 3} \fallingdotseq 1.5 \mathrm{~m}$ の波が数 回来襲した。

以上のことから次のような解釈が可能となる．波高が ある程度大きい場合は, 汀線付近に存在していた粗い砂 を前浜上に輸送するだけの掃流力が生じるので粗砂と細 砂による層状の断面が形成される．また波の打ち上げ高 も大きいためバームは大きく発達する．逆に波高が小さ いと，掃流力が小さいため細砂が堆積するのみである. また，打ち上げ高も小さいためバーム高は低くなる．次 節ではこれらの点について定量的に検討する.

\section{4. 波浪，底質条件とバームの形成との関係}

バーム内の層状構造の有無や, バームの高さの相違は, 波浪条件や底質粒径に強く依存する. そこで，波浪条件 と底質粒径の変化が，バームの形成過程に及ぼす影響を 定期観測のデータを用いて詳細に検討した.

定期観測によれば，1975 年 6 月より 1986 年 12 月の 間にバームは合計 63 回形成された。このうち，波浪お よび底質のデータが整っている 41 組のデータを用いて， バームの高さと底質粒径, 波浪条件の関係を調べた.バー ムの高さの代表值としてバームが最も成長したときの高 さ $Z_{B \max }$ をパラメーターとして, 週平均した入射波のエ ネルギーフラックス $\bar{F}$ と底質の中央粒径 $d_{50}$ により, 式（1）に基づく前浜の侵食・堆積の分類図上に図示し た（図一15).ここに $\bar{F}$ はバーム高さが最大となる日時 に先立つ 1 週間のデー夕を平均して求めた. また $d_{50}$ は $\mathrm{P}_{0}$ 地点の 1 週間前の底質粒径である. 前浜の侵食・堆 積の判定図においては, 前浜勾配が重要なパラメーター 


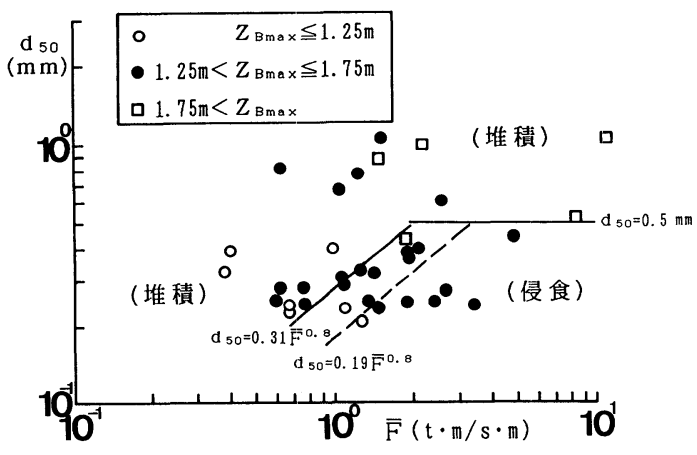

図-15 侵食・堆積の区分図上での $Z_{B \max }$ の分布

となる. 本研究の場合, バーム高が最大となる 1 週間前 の前浜勾配 $i_{f}$ は平均して 0.051 であった. そこで, 図 中には $0.04 \leqq i_{f} \leqq 0.06$ の場合に求められた堆積・侵食 の区分線を示した (表一1参照). 実線は侵食データの みより判断した区分線, 破線は堆積データのみより判断 した区分線である.データの多くは前浜が堆積傾向を示 す領域にある.また， $\bar{F}$ および $d_{50}$ が小さいと $Z_{B \max }$ も 小さく, $\bar{F}$ と $d_{50}$ が大きいときには $Z_{\text {Bmax }}$ も大きくなる 傾向がある. 結局, $d_{50}$ が小さい場合, $\bar{F}$ がある程度大 きくなると前浜は堆積傾向ではなくなり, バームの成長 が止まるため, バーム高さは低くなる.一方, $d_{50}$ が比 較的大きい場合には, ある程度 $\bar{F}$ が大きくてもバーム の堆積傾向が維持される. そのため, バーム高も高くな る. 以上の点より, バームの形成は波浪条件だけでなく, 底質粒径によっても強く支配されることがわかった。

次にバームの形成過程に着目し, バームが 2 週間以上 成長し続け, かつ波浪, 底質のデータが整っている 12 例（表一2参照）のデータより分析を進めた。バームの 成長を代表するパラメーターとして, 1 週間のバーム高 の変化量 $\Delta Z_{B}$ を用い, その 1 週間の平均エネルギーフ ラックス $\bar{F}$ と $\Delta Z_{B}$ との関係を調べた（図一16).この 場合, バーム高の変化の生ずる 1 週間前の值の代表値亡 して $\mathrm{P}_{0}$ 地点の $d_{50}$ をパラメーターとした. $\bar{F}$ が増加す ると $\Delta Z$ も増加する傾向が明らかである. また，侵食 データのみより判断した区分線（図一15, 破線）の関係 に $d_{50}=0.5 \mathrm{~mm}$ および $0.3 \mathrm{~mm}$ を代入して得られた $\bar{F}$ の值を図中破線で示した.この破線は $d_{50}=0.5 \mathrm{~mm} の$ 場合は $\bar{F} \geqq 2.1$ で, $d_{50}=0.3 \mathrm{~mm}$ の場合は $\bar{F} \geqq 1.1$ でそ れぞれ侵食傾向となることを示す．各デー夕は, $d_{50} \leqq 0.3 \mathrm{~mm}$ の場合に $\bar{F}=1.1$ を上限として, また 0.3 $\mathrm{mm} \leqq d_{50}<0.5 \mathrm{~mm}$ の場合に $\bar{F}=2.1$ を上限として分布 している.このように, バーム発達時の $\bar{F}$ は $d_{50}$ ごと に定まる沖向き漂砂の発生限界の $\bar{F}$ よりさくなる. 結局, 波浪作用時の前浜の底質粒径がバームの発達およ び大きさに影響を与えることが明らかである，さらに，
表一2 検討に用いた資料一覧

\begin{tabular}{|c|c|}
\hline バーム存在期 間 & 粗粒化の有無 \\
\hline Ju 1 y $22.1976 \sim$ A u g. 11 & $x$ \\
\hline May $31.1979 \sim \mathrm{Jul} 1$ y 12 & $x$ \\
\hline June $12,1980 \sim \mathrm{Jul} 1 \mathrm{y} 3$ & $x$ \\
\hline Mar. $3.1983 \sim \mathrm{Apr} .21$ & 0 \\
\hline Apr. $\quad 4.1985 \sim$ Apr. 25 & 0 \\
\hline May $8.1986 \sim$ June 12 & 0 \\
\hline Ju 1 y $21,1977 \sim$ A u g. $\quad 4$ & $x$ \\
\hline Nov. $8.1979 \sim$ Nov. 30 & 0 \\
\hline Aug. $5,1982 \sim$ A ug. 19 & $x$ \\
\hline Nov. $10,1983 \sim$ Dec. 1 & 0 \\
\hline Apr. $3.1986 \sim$ Apr. 17 & $\times$ \\
\hline Sep. $11.1986 \sim$ Sep. 25 & $x$ \\
\hline
\end{tabular}

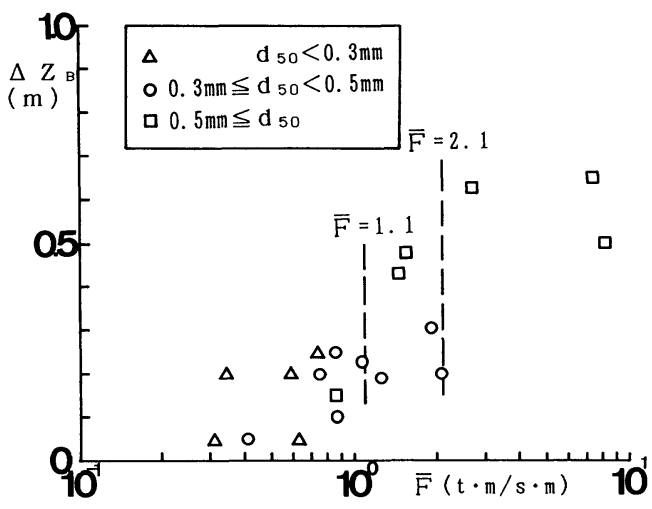

図-16 $\Delta Z_{B}$ と $\bar{F}$ の関係

$\left(d_{50}\right.$ はバーム成長開始 1 週間前の值 $)$

$\Delta Z_{\text {в }}$ は 1 週間の間のバームの成長高を表わすことから， バームの成長速度は岸向き漂砂が生じる条件の範囲内に おいて, $\bar{F}$ が大きいほど速いことになる.

以上の議論において,$d_{50}$ は地形変化の生ずる前の データを用いているため, 必ずしも波の作用により移動 した底質の特性值を示さない場合がある。 そこで, 波浪 が作用した後の底質粒径を用いて， $\Delta Z_{B}$ および波浪条 件の関係を同様に調べた（図一17）。この場合も図-16 とほぼ同じ関係が成立する.このことからバーム形成時, 前浜沖に細砂，粗砂が十分あるとすれば， $\bar{F}$ が大きい ときにはそれに応じて粒径の大きな底質が前浜に堆積す ることが明らかである。

前節ではバームが大きく成長するときに層状構造が形 成されると述べたが，ここではこの点をさらに詳しく検 討する. まず表一 2 に示す 12 例について，バーム形成 


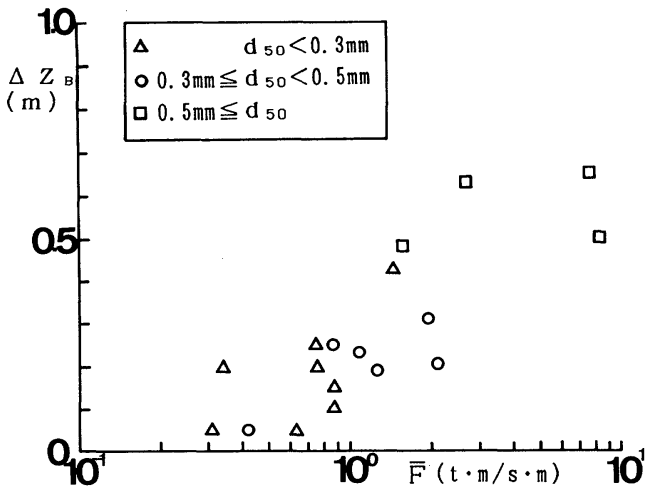

図一17 $\Delta Z_{B}$ と $\bar{F}$ の関係 $\left(d_{50}\right.$ はバーム成長後 $)$

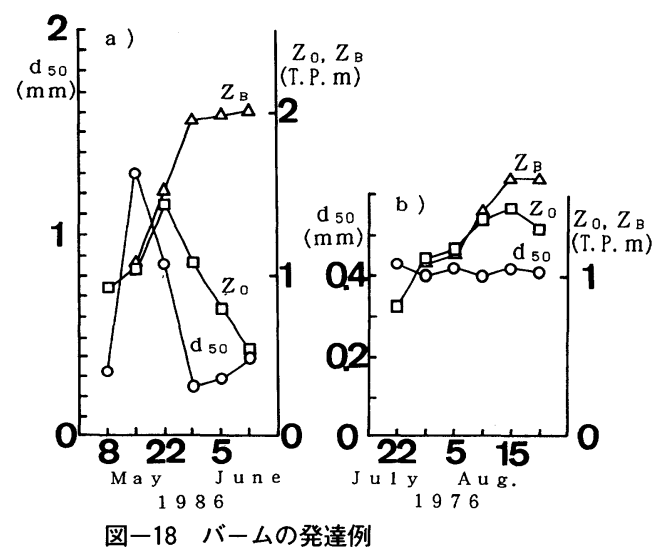

a) 1986 年 5 月 8 日 6 月 12 日,

b) 1976 年 7 月 22 日 8 月 26 日

時の $\mathrm{P}_{0}$ 地点の底質中央粒径 $d_{50}$ の経時変化を調べた. その結果, バームの成長状況と底質粒径の変化は 2 種類 のタイプに分けられることがわかった. 代表例を図-18 に示す. 図には $d_{50}$ が変化する際の前浜地形変化を調べ るために, $Z_{B}$ および $\mathrm{P}_{0}$ 地点の地盤高 $Z_{0}$ の経時変化も 併記した。図一 18 a) では 5 月 15 日に $d_{50}=1.3 \mathrm{~mm}$ と 粗粒となったが， 5 月 29 日には $d=0.25 \mathrm{~mm}$ と再び細 粒となった。この間， $Z_{0}$ は 5 月 22 日まで増加し，その 後減少した。 また， $Z_{B}$ は 5 月 29 日まで増加しその後安 定した。このように，a）はバーム形成時に一時的に粗 粒の底質がみられる場合である，b) では， $Z_{B}$ および $Z_{0}$ が増加し，バームが成長しているにもかかわらず, $d_{50}$ はほぼ一定值を示す。これは均一砂のみが前浜に堆 積したことを表わしている. 以上のようにバームの形成 過程には，一時的に底質が粗粒となる場合と，均一な細 砂が堆積する場合とがある. 前出の表一2には，これら の分類を行った結果も併せて示した. 12 ケースのうち 5 ケースで粗粒化がみられ，他の 7 ケースでは均一砂の 堆積がみられた。さうに, 粗粒化の有無ごとにバームが

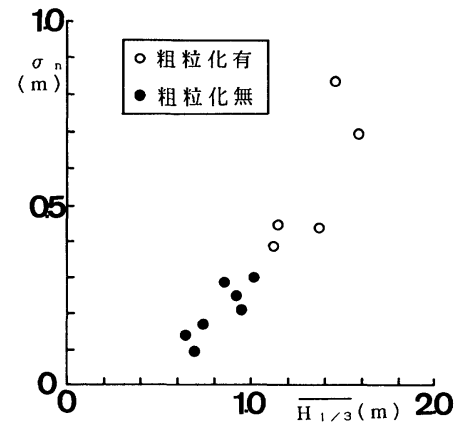

図-19 $\overline{\boldsymbol{H}_{1 / 3}}$ と $\sigma_{n}$ による粗粒化の有無の分類

出現し始めたときの $Z_{B}$ とバームが最も高くなったとき の $Z_{\text {Bmax }}$ の差を求めて比較したところ, 粗粒化が生じる 場合, この差は $0.6 \sim 1.25 \mathrm{~m}$ であったのに対して, 生 じない場合には $0.05 \sim 0.45 \mathrm{~m}$ であった. すなわち, バー ムが大きく成長する場合に粗粒化が生じ，あまり成長し ない場合は細砂が堆積していたことがわかった。

前浜の底質粒径に変化が生じる場合, バームの成長は 大きく，またそのときの $\bar{F}$ は大きな值であった（図一 15 参照). 阿字ケ浦海岸では, 高波浪の継続期間は数日 程度である.したがって, バームが形成される数週間の 間には波浪条件は変動したはずである，バーム形成時に おいては, 入射波のエネルギーフラックスと底質粒径と の間にある関係が成立し，エネルギーフラックスが大き いほぼ底質粒径は大きかった。 そこで各バームが形成さ れた期間の日平均沖波有義波高の平均值 $\overline{H_{1 / 3}}$ と, その 標準偏差 $\sigma_{n}$ を $\mathrm{P}_{0}$ 地点の底質粒径変化の有無ごとに分類 し図一19に示す．図によれば $\overline{H_{1 / 3}}$ および $\sigma_{n}$ とも小さ な值のときには粗粒化はなく, $\overline{H_{1 / 3}}, \sigma_{n}$ ともに大きい ときに粗粒化が生じた.すなわち, 波高が平均的に高く, さらに時間的変動が大きいとき, 前浜の底質粒径が変化 することが明らかである. 粗砂が堆積するためにはある 程度波高が高い必要がある. また，バームが大きく成長 するためにもある程度の高波浪が必要となる。したがっ て高波浪と静穏な波浪が交互に来襲する場合に波浪条件 に応じた底質が前浜に堆積して層状構造のバームが形成 され，かつ，バームも大きく成長することになる.

\section{5. 結 論}

（1）汀線付近における Net の岸沖漂砂の移動方向 を沖波エネルギーフラックス, $\mathrm{P}_{0}$ 地点での底質の中央 粒径および前浜勾配で整理した結果, 前浜の侵食と堆積 を分類することができた。 中央粒径が $0.5 \mathrm{~mm}$ 以上では ほとんよ゙の場合堆積となり，それ以下では式（1）に示 す関係で分類された。この関係式の定数は前浜勾配に よって変化し, 前浜勾配が大きいほざ侵食されやすい傾 
向となる.

（2）バームは粗砂と細砂が交互に堆積してできる場 合と均一砂が堆積してできる場合とがある. バームが層 状構造を示す場合, バーム高さの増加量は 0.6 1. $25 \mathrm{~m}$ であったのに対し，層状構造のない場合では 0.05〜 $0.45 \mathrm{~m}$ であり, 層状構造を有するバームの方が成長が 著しかった。

（3）入射波のエネルギーフラックスが大きいとき， バームの成長は速やかであり，かつ粗砂が堆積する．一 方, 入射波のエネルギーフラックスが小さいときには, バームの成長は遅く細砂が堆積する。 バームの成長は入 射波のエネルギーフラックスと底質粒径に強く依存す る.

（4）バームが層状に堆積したときには来襲波の標準 偏差が大きかった．バームの層状構造の形成原因は，入 射波のエネルギーフラックスの変化に伴って前浜に堆積 する底質の粒径が変化することによる.

謝辞：沖波波浪データは運輸省鹿島港工事事務所 の方々に便宜を図って頂いた。ここに記して謝意を表し ます。

\section{参 考 文 献}

1) Rector, R. L. : Laboratory study of equilibrium profiles of beaches, BEB Teçh. Memo. No. 41, 1954.

2) Nayak, I. V. : Equilibrium profiles of model beaches, Proc. 12 th Conf. Coastal Eng., pp.1321 1329, 1970.

3) Sunamura, T. : Quantitative predictions of beach-face slopes, Geol. Soc. Am. Bull., Vol. 95, pp. 242 245, 1984.

4) 武田一郎・砂村継夫 : バームの形成条件と高さ, 地形, Vol. 3, pp. 145 157, 1982.

5）岩垣雄一・野田英明：海浜変形の実験における縮尺効果 の研究, 第 8 回海岸工学講演会講演集, pp. 138 143, 1961.

6) Johnson, J.W. : Scale effects in hydraulic models involving wave motion, Trans. Am. Geophy. Union, Vol. 30, pp. 517 525, 1949.
7）堀川清司・砂村継夫・近藤浩右・岡田 滋：波による二 次元汀線変化に関する一考察, 第 22 回海岸工学講演会論 文集, pp. 329 334，1975.

8) Kemp, P.H. : The relationship between wave action and beach profile characteristics, Proc. 7 th Conf. Coastal Eng. , pp. 262 277, 1968 .

9）服部昌太郎・川又良一：砕波帯内の海浜変形過程, 第 25 回海岸工学講演会論文集, pp. 218 222, 1978.

10）宇多高明 - 小俣 篤・竹㴊 勉 - 斉藤友伸：前浜地形変 化と砕波帯内における浮遊砂の発生・輸送機構に関する 現地観測報告書, 土木研究所資料, 第 2672 号, 62 p. , 1988.

11）橋本 宏・宇多高明：前浜勾配，粒径および波高の動的 関係について，第 27 回海岸工学講演会論文集, pp. 221 $\sim 225,1980$.

12）宇多高明 - 小俣 篤・竹㴊 勉 - 斉藤友伸：浮遊砂の砕 波帯内における輸送機構に関する現地観測, 第 43 回年次 学術講演会講演概要集, pp. 732 733, 1988 .

13）加藤一正・柳嶋慎一・村上裕幸 - 末次広児：短期汀線変 動のモデル化の試み, 第 34 回海岸工学講演会論文集, pp. 297 301, 1987.

14) Clifton, H.E. : Beach lamination; Nature and origin, Marine Geol., Vol. 7, pp.553 559, 1969.

15) Uda, T. and Sakai, Y. : Summarized data of beach profiles and wave observations at Ajigaura Beach, Tech. Memo. PWRI, No.2294, 286 p., 1985.

16）宇多高明-小俣 篤・竹㴊 勉：波による前浜地形変化 の支配要因, 第 35 回海岸工学講演会論文集, pp. 337 341,1988

17）宇多高明・小俣 篤・竹㴊 勉：阿字ヶ浦海岸における 波による前浜地形の変化，土木技術資料，Vol. 30 No. 4, pp. 15 20, 1988.

18）砂村継夫：自然海浜における汀線位置の時間的変化に関 する予測モデル，第 27 回海岸工学講演会論文集, pp. 255 259， 1980 .

19）砂村継夫：Swash zone を含む砕波帯の岸沖漂砂量に関す る研究, 第 31 回海岸工学講演会論文集, pp. 316 320, 1984.

20）田中則男・加藤一正・灘岡和夫 : 砕波帯内における浮遊 砂濃度分布, 第 26 回海岸工学講演会論文集, pp. 182 $186,1979$.

（1989.4.18 • 受付） 